\title{
The Mediation Effect of Organizational Commitment in the Relation of Organization Culture and Employee Performance
}

\author{
A. Adam *, T.Yuniarsih, E. Ahman, K. Kusnendi \\ Universitas Pendidikan Indonesia \\ Bandung, Indonesia
}

\begin{abstract}
The present study investigate the relation of organization culture and employee performance and the mediation role of organizational commitment. The research conducted in a local public company who served clean water to the society. Non-probability sampling method with accidental sampling technique was used to gather 260 employees to participate in this study. Descriptive and verificative method were used to analyze the relation between variables through hypothesis testing. The study found that organizational culture has significant effect on employee performance. Meanwhile organizational commitment proved to be a mediator in the relation. Organization should develop strong culture and commitment in order to enhance employee performance.
\end{abstract}

Keywords-Organizational Commitment; Organization Culture; Employee Performance

\section{INTRODUCTION}

According to [1] organization performance greatly affected by their human resources. It is also believed that human resources play an important role in helping the organization to thrive and win the competition. To boost their performance, organization need to drive their human resources to excel. All employees must maintain great performance. The state-owned water company (PDAM) in Purwakarta although they do not have actual competition but they need to serve their customer better. [2] argued that PDAM's performance to meet the customer demand is still low. This is exacerbated by the increasing of population which makes more difficult to provide clean water. Based on research from [3] only $20 \%$ of the Indonesian population enjoy the clean water from PDAM.

In Purwakarta the situation is not different. [4] convey that in May PDAM service was down for 36 hours. In 2016 the same problems still exist [5]. To overcome these problems Head of Purwakarta Regency, Dedi Mulyadi provides PDAM with Rp 33 billion to improve the facilities and infrastructure which related to the water supply [6]. Furthermore, the Head of Regency also insists that PDAM should improve its customer service especially in the way they handle the complaint [7].
Despite these enourmous challenges, PDAM Purwakarta also has problems regarding their employee performance. One indicator which can be related to the performance is the attendance and disciplinary report. According to the internal report, in 2015 there are negative trend regarding the employee absenteeism. The number of employees who was not come to work without notice increase $18.84 \%$ from previous year. Another poor records came out from the number of employee who was sick, increase $66.9 \%$ from 2014. With such unsavory records, PDAM need to improve their human resources performance. Moreover, the Head of Regency also emphasizes that PDAM should change the way they conduct the business. They have to become more professional to catch up with the customer demand.

\section{LITERATURE REVIEW}

2.1 The current study investigate the effect of organization culture on employee performance with the mediation of organizational commitment. Company need to develop strong culture which can provide positive work environment to drive the performance. Meanwhile, the organizational commitment also believed to have positive impact on performance. Highly commited employee tend to give their best at work. The study hopefully can help the company to improve the employee performance by applying the right instruments.

A. Organization culture and organizational commitment

Corporate culture considered a critical factor when organization needs to enhance or pursue their goals and objectives. The core value inside the organization culture can guide the employee to achieve more. Thus, we can say that the effectiveness of an organization might be influenced by organizational culture. Culture usually brought to practices in terms of how management manage their planning, organizing, controlling, evaluation were carried out. Strong corporate culture would enable employees to easily understand the company's goals. Organization culture is a vital foundation in developing and sustaining commitment. The more employee felt they fit with the culture, they will work towards organizational goals and then drive the increase of commitment. In a study in India, [8] used 200 middle level 
entrepreneurial culture and consensual culture statistically have significant and positive effects on employee performance. Further research from [21] claimed that strong culture of an organization based upon the action of managers and leaders would help improving employee's performance. Finally, [22], [23] both studies found significant positive correlation between organizational culture and employee's performance. It is vital to make organizational culture strong in order to enhance the job performance of employees. Based on the result from previous literatures, we determine the second hypothesis as;

$\mathrm{H} 2$ : Organization culture will have significant positive effect on employee performance.

C. Organizational commitment and employee performance

Employes are willing to give more to their jo if they felt interested or committed. They will perform better and even exceed the standard. Such behavior will certainly have positive impact on organization performance. Strong organizational commitment has been believed as critical success to achieve higher performance. Enhancing organizational commitment among employees is an important aspect to perform better since the success of organization very much depends on the performance of its employees. We studied several previous academic articles that tend to reinforce the notion that organizational commitment has significant positive relationship with employee performance. Research in Indonesia by [24] found that organizational commitment significantly influence employee performance directly or indirectly through work satisfaction. A study in oil and gas sector in Pakistan [25] revealed positive relationship between organizational commitment and employees' job performance. Using employee from educational industry as participant, Tolentino in Manila 2013 found that only affective commitment correlates significantly with job performance. Meanwhile among the administrative staff, not a single commitment dimension is related to job performance. This result gives new perspective that different type of jobs might reveal different result. Meanwhile, [26] revealed a positive relationship between organizational commitment and employee's performance in banking industry in Iran. Reseach from Indonesia using 115 employees in a district hospital [27] showed that organizational commitment has a positive and significant impact on employee performance. Other studies that support a positive influence came from [28] in Bali, [29] in Nusa Tenggara Indonesia, [30] in Iran, and [31] in Pakistan. They are all argued that the more committed employees for their organization, the more possible they tend to foster their performance. Indeed the organizational commitment had a positive significant effect on the job performance. Contrary to the other result, [32] studied 274 Portuguese workers and argued that commitment components did not present

significant predictor strength for employee performance. This performance. Using subdimension for organization culture, [20] in Somalia argued that competitive culture, 
C. Measurement

A questionnaire consisted of total 89 items (28 items for organization culture, 15 items for job satisfaction, 14 items for organizational commitment, 12 items for work discipline, and 20 items for employees performance) used to collect the data. Each item has 5 choices of answers based on Likert's scale option from 1 - strongly disagree, 2 - disagree, 3- neither agree nor disagree, 4 - agree, and 5 - strongly agree. Cronbach's Alpha for internal consistency reliability for items representing organizational culture was .957; for job satisfaction was .955; for organizational commitment was .897 ; for work discipline was .869; and for employee performance was 907

\section{RESUlT AND DisCUSSION}

Table 2 present the model coefficients and other statistics information resulted from the mediation analysis obtained from a macro program [33] using SPSS. Organization culture had significant positive effect on organizational commitment (p-value 0.000) and employee performance ( $\mathrm{p}$-value 0.000). Organizational commitment had significant positive effect on employee performance ( $\mathrm{p}$-value 0.000).

Table 2. Regression coefficient, standard error, \& model summary. which mean they already receive full benefit from organization. Most of PDAM employees pertained happy in their job. This is indicated by the highest percentage $(37 \%)$ had more than 5 years of service. Table 1 display detail information regarding the demographic aspects.

Table 1. Demographic aspects.

\begin{tabular}{lllll}
\hline $\begin{array}{l}\text { Demographisc } \\
\text { Factor }\end{array}$ & Classification & $\begin{array}{l}\text { Number of } \\
\text { Respondent }\end{array}$ & Total \\
\hline Sex & Male & 146 & $56 \%$ & $100 \%$ \\
Age & Female & 114 & $44 \%$ & \\
& $18-30$ & 75 & $29 \%$ & $100 \%$ \\
& $>30-40$ & 114 & $44 \%$ & \\
Employement & $>40-50$ & 55 & $21 \%$ & \\
Length & $>50$ & 16 & $6 \%$ & \\
Service & Reguler & 231 & $89 \%$ & $100 \%$ \\
& Contrat & 29 & $11 \%$ & \\
& $<1$ year & 34 & $13 \%$ & $100 \%$ \\
& $1-3$ years & 49 & $19 \%$ & \\
& $>3-5$ years & 77 & $30 \%$ & \\
& $>5-10$ years & 39 & $15 \%$ & \\
\hline & $>10$ years & 61 & $23 \%$ & \\
\hline
\end{tabular}

B. Data analysis

To test the significance of organizational commitment as mediation, bootstrapping approach using the PROCESS Macro for SPSS 23 was used [33]. Bootstrapping approach considered as appropriate because it do not require normality assumptions of the sampling distribution through the application of bootstrapping confidence intervals [34]. Macro for SPSS facilitates quite easy bootstrapping equation. The tool shows the significance of mediation effects if Upperlevel and Lower level Confidence Interval contain no zero value.

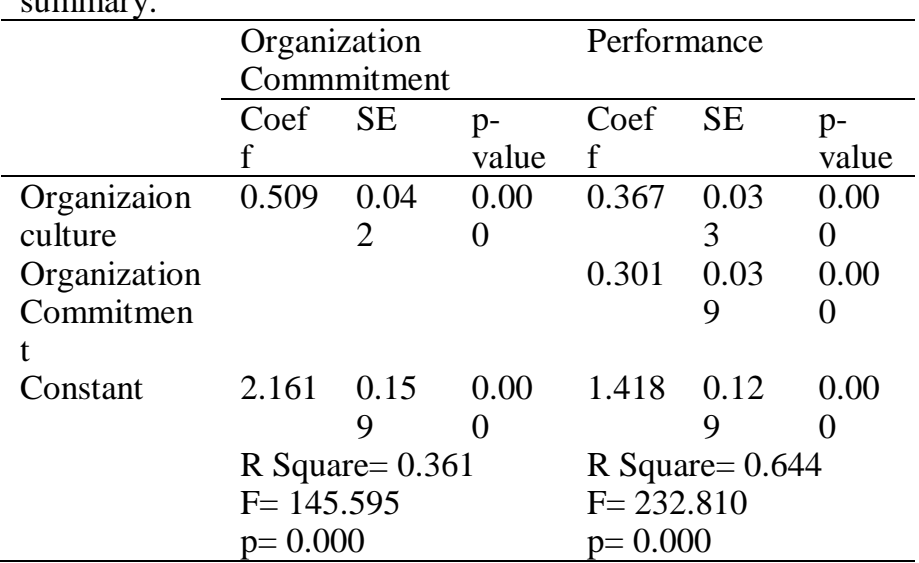

This means hypothesis $\mathrm{H} 1, \mathrm{H} 2$ and $\mathrm{H} 3$ all were accepted. Employee in PDAM who perceive stronger organization culture will show higher commitment and perform better. Meanwhile, employee who perceive higher organizational commitment also had impact on their performance. That is the management can use both culture and commitment to improve the employee performance.

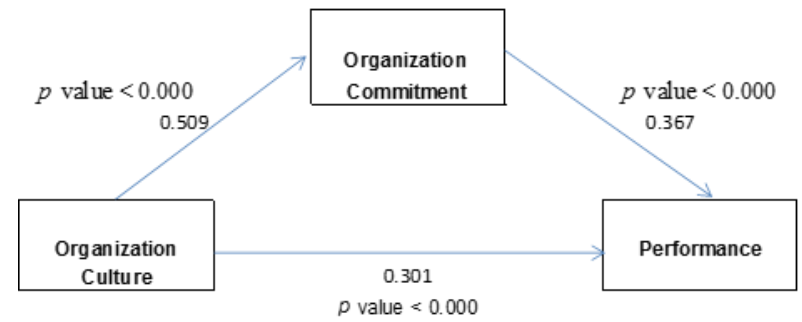

Figure 1: The Mediation model. 
Organization should build strong and positive culture which correspond to the employee. After they established great culture the process of socialization of the culture must be done immediately with the right method. Then the management have to embed the culture in every decision, policy, and action. Only with such continuous implementation, then employees gradually would understand and implement the culture. Understanding and implementation of organizational culture will strengthen the organizational commitment which in the end will affect the performance.

Table 3 showed the total, direct, and indirect effect of organization culture on employee performance. As we can see from te table, total effet was bigger than direct effect which mean, the organizational commitment had significant positive mediation effect. This is corroborated by the Lower Level Confidence Interval (LLCI) and Upper Level Confidence Interval (ULCI) both did not have zero value.

Table 3: Total, direct, \& indirect effect.

Total Effect of Organization Culture on Employee
Performance

$\begin{array}{llllll}\text { Effect } & \mathrm{SE} & \mathrm{t} & \mathrm{p} & \text { LLCI } & \text { ULCI } \\ 0.5239 & 0.291 & 17.9782 & 0.0000 & 0.4666 & 0.5813\end{array}$

Direct Effect of Organization Culture on Employee Performance

$\begin{array}{llllll}\text { Effect } & \text { SE } & \mathrm{t} & \mathrm{p} & \text { LLCI } & \text { ULCI } \\ 0.3671 & 0.327 & 11.2313 & 0.0000 & 0.3028 & 0.4315\end{array}$

Indirect Effect of Organization Culture on Employee Performance Through Organization Commitment

\begin{tabular}{lllll} 
ORGCOMM & Effect & Boot & Boot & Boot \\
& & SE & LLCI & ULCI \\
& 0.1568 & 0.264 & 0.1073 & 0.2114 \\
\hline
\end{tabular}

In PDAM case employee performance can be improved using approach related to culture and commitment. PDAM already develop strong culture and the positive side is that employee perceived such culture somewhat suitable fot them. It is up to the management to take advantage from this situation. Routine communication, good relationship between peers, good system $\&$ work procedures, the way they took decision and solving the problems, should be formalized. Formal way of doing in PDAM then can become more useful if employees instill in their works. When employees work with their heart, they become more committed and usually follow by increase in performance.

The present study support previous literatures regarding the relation of organization culture, organizational commitment, and emplyee performance. Study in India [8], Hongkong and Australia [8], Taiwan [10], US and China [11] reveal significant relations between perceived organizational culture and work attitudes (organizational commitment). Our study also shows the significant and positive relation between culture and organizational commitment. Both in western and eastern culture, it was proved that organizational culture can become a driver to boost organizational commitment.

Researches that discuss organizational culture and employee performance has often been done. [16] stated that organization culture has a significant positive impact on employee's job performance. Other study which reveals the same conclusion conducted in India [17], Kenya [18]; [19], and [20]. Furthermore, study from [21] also mentions that culture of an organization based on the action of managers and leaders would help improving employee's performance. The same notion delivered by [22], [23]. Indeed, the organization culture would positively impact employee performance.

The next previous researches studied the relation of organizational commitment and employee performance. [24] found significant influence of organizational commitment on employee performance. Study from Pakistan [25], [31], Phillipine [35], Indonesia [27], [28], [29], and Iran [26], [30] found the same direction. The difference result presented by (Cesario \& Chambel 2017) who studied Portuguese workers and found that commitment components did not predict employee performance.

\section{MANAGERIAL IMPLICATION}

Public company should aware that development of strong culture would drive organizational commitment which in the end will have impact on employee performance. The result suggests that managers have to set the way organization do and conduct the business. Then they have to become the first to implement the organization way before it passes on the all employees. For example if they want result oriented and disciplined work environment, then they should show seriousness. Only then the lower level of employees can understand and take such positive action to change and adjust to the new culture.

Management can rely on their human resources department to create program to introduce new culture. A set of training inside and outside the organization can help employee more quickly to adjust. Outbound program can enhance the sense of cooperation between departments. Implement a rotation also can increase employee awareness for different department so they would not give negative judgment. Human resources department could propose other comprehensive program which fit with organization's need.

\section{CONCLUSION}

All three hypotheses were accepted, organization culture significantly positive affect organizational commitment and employee performance, while organizational commitment has significantly positive effect on performance. Employees in PDAM perceive that they were fitted with the culture the company developed, they also have high organizational commitment and perceive their performance was met the organization standard. The latter is debatable because employee answers the question using self-evaluation. Management needs to discuss the differences to improve the overall performance. They should investigate what causes the customer's complaint or any other deficiencies. From the result, PDAM could develop its culture to enhance commitment and in the end affecting the performance. The result adds to the enrichment of the discussion regarding organizational culture, commitment, and employee 
performance.

\section{REFERENCES}

[1] Bartel, A.P. 2004. Human resource management and organizational performance: Evidence from retail banking. Industrial and Labor Relations Review 57(2): 181-203

[2] Hadipuro, W. 2010. Indonesia's water supply regulatory framework: between commercialisation and public service?. Water Alternatives 3(3).

[3] Peniwati K, and Brenner.,B, 2008, "Multi-decisions rating model: establishing rescue policies for regional drinking water companies (PDAMs) in Indonesia". European Journal of Operational Research 186(2008): 1127-1136.

[4] Nugraha, M. 2015. 36 Jam Terputus, PDAM Purwakarta Minta Maaf. http://jabar.tribunnews.com/2015/05/24/36-jam-terputus-pdampurwakarta-minta-maaf.

[5] Hidayat, S. 2016. Pelanggan PDAM Purwakarta Keluhkan Layanan Air Sering Tak Mengalir. http://www.purwakartapost.co.id/11/01/2016/ekonomi/pelanggan-pdampurwakarta-keluhkan-layanan-air-sering-tak-mengalir/615/.

[6] Khumaini, M.A. 2016. Pemkab Purwakarta Kucurkan Rp33 Miliar https://megapolitan.antaranews.com/berita/20783/pemkab-purwakartakucurkan-rp33-miliar-untuk-pdam.

[7] Khumaini, M.A. 2016. Bupati Purwakarta Minta PDAM Perbaiki Sistem Pengaduan. https://megapolitan.antaranews.com/berita/20785/bupatipurwakarta-minta-pdam-perbaiki-sistem-pengaduan.

[8] Tripathi, S., Kapoor, A. \& Tripathi, N. 2000. Organisational culture and organisational commitment. Indian Journal of Industrial Relations 36(1): 24-40.

[9] Lok, P. \& Crawford, J. 2004. The effect of organisational culture and leadership style on job satisfaction and organisational commitment a cross-national comparison. Journal of Management Development 23(4): 321-338.

[10] Silverthorne, C. 2004. The impact of organizational culture and personorganization fit on organizational commitment and job satisfaction in Taiwan. The Leadership \& Organization Development Journal 25(7): 592-599

[11] Shelton, C., Gartland, M. \& Stack, M. 2011. The impact of organizational culture and person-organization fit on job satisfaction and organizational commitment in China and the USA. International Journal of Management Development 1(1): 15-39.

[12] Nongo, E.S. \& Ikyanyon, D.N. 2012. The influence of corporate culture on employee commitment to the organization. International Journal of Business and Management 7(22): 21-28.

[13] Azizollah, A., Abolghasem, F., \& Amin, D.M. 2016. The relationship between organizational culture and organizational commitment in Zahedan University of Medical Sciences. Global Journal of Health Science 8(7): 195-202.

[14] Firuzjaeyan, A.A., Firuzjaeyan, M., \& Sadeghi, B. 2015. A survey of the effect of organizational culture on organizational commitment based on Allen and Meyer model (Case study: High school teachers of Bandpey region). International Journal of Academic Research in Business and Social Sciences 5(1): 1-9.

[15] Rashid, Z.A., Sambasivan, M., \& Johari, J. 2003. The influence of corporate culture and organisational commitment on performance. Journal of Management Development 22(8):708-728.

[16] Shahzad, F. 2014. Impact of organizational culture on employees' job performance: An empirical study of software houses in Pakistan. International Journal of Commerce and Management 24(3): 219-227.

[17] Gunaraja, T.M. 2014. Organizational corporate culture on employee performance. Journal of Business and Management (IOSR-JBM)16(11): $38-42$.

[18] Wambugu, L.W. 2014. Effects of organizational culture on employee performance (case study of Wartsila - Kipevu Ii power plant). European Journal of Business and Management 6(32): 80-92.

[19] Wanjiku, N.A. \& Agusioma, N.L. 2014. Effect of organisation culture on employee performance in non govermental organizations.
International Journal of Scientific and Research Publications 4(11): 112.

[20] Dahie, A.M., Takow, M.A., Nur, A.H. \& Osman, M.M. 2016 Organizational culture and employee performance at telecommunication firms in Mogadishu, Somalia. International Journal in Commerce, IT \& Social Sciences 3(1): 30-41.

[21] Awadh, A.M. \& Saad, A.M. 2013. Impact of organizational culture on employee performance. International Review of Management and Business 2(1): 168-175

[22] Mohamed, A.I. \& Abukar, A.A.S. 2013. The impact of organizational culture on employees performance of Mogadishu Universities. Academic Research International 4(6): 382-391

[23] Menaka, W.H.S. \& Chandrika, K.A.C. 2015. Impact of organizational culture on employee job performance in a large scale apparel company (BASL-Finishing). 2nd International HRM Conference 2(1): 65-74

[24] Syauta, J.H., Troena, E.A., Setiawan, M., Solimun, S. 2012. The influence of organizational culture, organizational commitment to job satisfaction and employee performance (study at municipal waterworks of Jayapura, Papua Indonesia). International Journal of Business and Management Invention 1(1): 69-76.

[25] Khan, M.R., Ziauddin, J.F.A. \& Ramay, M. I. 2010. The impacts of organizational commitment on employee job performance. European Journal of Social Sciences 15(3): 292-298.

[26] Memari, N., Mahdieh, O., \& Marnani, A.B. (2013). The impact of Organizational Commitment on Employees Job Performance. "A study of Meli bank. Interdisciplinay Journal of Contemporary Research in Business, Vol. 5, No. 5, 164-171.

[27] Hakim, A. 2015. Effect of organizational culture, organizational commitment to performance: study in hospital of district South Konawe of Southeast Sulawesi. The International Journal of Engineering And Science (IJES) 4(5): 33-41.

[28] Dharmanegara, I.B.A., Sitiari, N.W. \& Adelina, M.E. 2016. The impact of organizational commitment, motivation and job satisfaction on civil servant job performance in State Plantation Denpasar. Journal of Business and Management (IOSR-JBM) 18(2): 41-50.

[29] Giri, E.E., Nimran, U., Hamid, D. \& Musadieq, M.A. 2016. The effect of organizational culture and organizational commitment to job involvement, knowledge sharing, and employee performance: A study on regional telecommunications employees of PT Telkom East Nusa Tenggara Province, Indonesia. International Journal of Management and Administrative Sciences (IJMAS) 3(04): 20-33.

[30] Rafieia, M., Aminib, M.T. \& Foroozandehc, N. 2014. Studying the impact of the organizational commitment on the job performance. Management Science Letters 4: 1841-1848.

[31] Dost, M.K., Rehman, Z., \& Tariq, S. 2012. Employee commitment and their performance are interrelated: A behavioral study From Pakistan". Kuwait Chapter of Arabian Journal of Business and Management Review 1(7): 125-139.

[32] Cesário, F. \& Chambel, M.J. 2017. Linking organization commitmen and work engagement to employee performance. Knowledge and Process Management, Published online in Wiley Online Library.

[33] Hayes, A.F. 2013. Introduction to Mediation, Moderation, and Conditional Process Analysis: A Regression-Based Approach. New York: The Gilford Press.

[34] Preacher, K.J., Rucker, D.D. \& Hayes, A.F. 2007. Addressing moderated mediation hypotheses: Theory, methods, and prescriptions. Multivariate Behavioral Research 42(1): pp. 185-227.

[35] Tolentino, R.C. 2013. Organizational commitment and job performance of the academic and administrative personnel. International Journal of Information Technology and Business Management 15(1): 51-59 